\title{
New State Records of the Slender Coralsnake, Calliophis melanurus (Shaw 1802), and the Yellow-spotted Wolfsnake, Lycodon flavomaculatus Wall 1907, in Chhattisghar, India
}

\author{
Rahul V. Deshmukh ${ }^{1}$, Sagar A. Deshmukh ${ }^{2}$, and Swapnil A. Badhekar ${ }^{3}$ \\ ${ }^{1}$ H. No. 26, Teacher colony, Brahmani - Kalmeshwar, Nagpur, M.S. - 441501 (rahul30.snake@gmail.com) \\ ${ }^{2}$ Behind Potdar Nursing Home, Kalmeshwar, Nagpur, M.S. - 441501 (sd.snakefriend@gmail.com) \\ ${ }^{3}$ Tiwaskarwadi, Raipur, Hingana, Nagpur, M.S. - 441110 (swapnilbadhekar86@gmail.com)
}

A sian Coralsnakes of the genus Calliophis (Elapidae) are among the most poorly known venomous snakes in southeastern Asia (Deepak et al. 2010; Ganesh and Ramanujam 2014). The Slender Coralsnake (C. melanurus), a nocturnal, ground-dwelling, oviparous species, is known to occur in India, Sri Lanka, and Bangladesh (Whitaker and Captain 2004) and might be present in Bhutan (Lenz 2012). In India, the species has been recorded from Gujarat, Kerala, Madhya Pradesh, Maharashtra, Karnataka, Tamil Nadu, and West Bengal (D’Abrue 1913; Deshmukh et al. 2015; Lewis et al. 2010; Nande and Deshmukh 2007; Palot 2015; Shine and Nameer 2012; Srinivasulu et al. 2014; Vyas and Vyas 1981; Whitaker and Captain 2004). We herein present the first records from Chhattisgarh.

On 7 December 2017, an adult male (SVL $191.96 \mathrm{~mm}$, tail length $18.42 \mathrm{~mm}$; Fig. 1) captured by Abid Khan from beneath a water tank at Steel Colony, Nehru Nagar, Street No. 8, Durg $\left(21^{\circ} 11^{\prime} 95.10^{\prime \prime} \mathrm{N}, 81^{\circ} 18^{\prime} 27.87^{\prime \prime} \mathrm{E}\right)$ regurgitated a young Brahminy Blindsnake (Indotyphlops braminus). A second Slender Coralsnake, a young male (SVL 130.09 mm, tail length $12.60 \mathrm{~mm}$; Fig. 1), was captured while crawling along a brick path in a house garden at about $0600 \mathrm{~h}$ on 9 December 2017 in the same area. A third individual, an adult female (SVL $168.01 \mathrm{~mm}$, tail length $13.21 \mathrm{~mm}$; Fig. 1) was in a drainage ditch lined with rocks at $0215 \mathrm{~h}$ on 12 December 2017. All were released into suitable habitat in the outskirts of Durg. These new records (Fig. 2) extend the distribution of this species about $242 \mathrm{~km}$ from the nearest known locality in Nagpur, Maharashtra, about $780 \mathrm{~km}$ from the nearest locality in Madhya Pradesh, about 1,000 km from that in West Bengal, 1,200 km that in Karnataka, and about 1,025 km from that in Andhra Pradesh.

The genus Lycodon, with 51 currently recognized species, is one of the most speciose genera in the Oriental Region (Uetz et al. 2018). The Yellow-spotted Wolfsnake (L. flavomaculatus), which Boulenger (1893) had considered a color variant of the Common Indian Wolfsnake (L. aulicus), is a rare Indian endemic (Whitaker and Captain 2004). It has been recorded with confidence from Gujarat, Madhya Pradesh, Maharashtra, Karnataka, and Tamil Nadu (Chikane
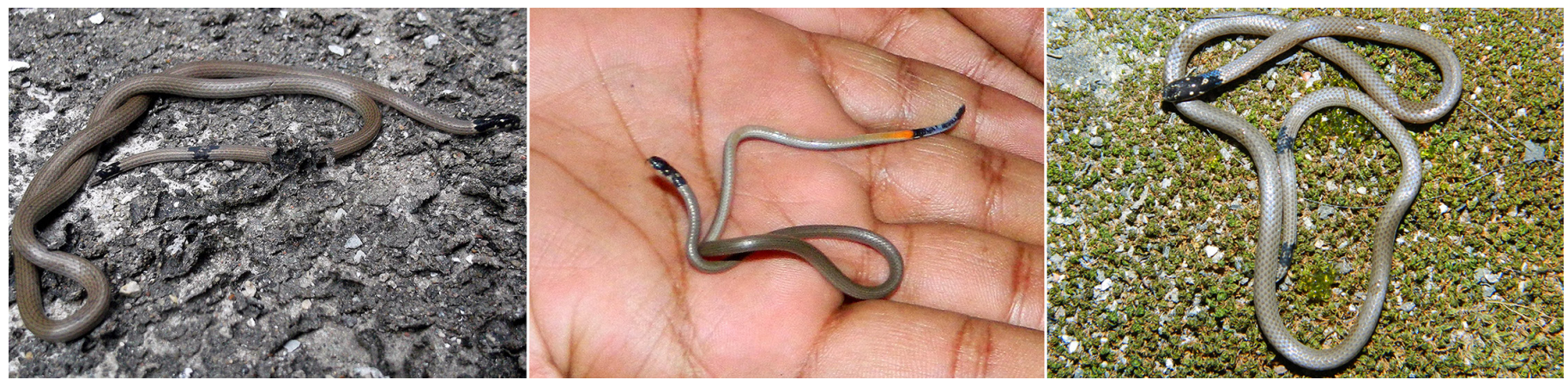

Fig. 1. Slender Coralsnakes (Calliophis melanurus) collected in the vicinity of Durg, Chhattisgarh, India: an adult male taken on 7 December 2017 (left), a juvenile male on 9 December 2017 (center), and an adult female on 12 December 2017 (right). These represent the first records of the species in Chhattisgarh. Photographs by Uddesh Hiwase (left), Rahul Deshmukh (center), and Sagar Deshmukh (right). 


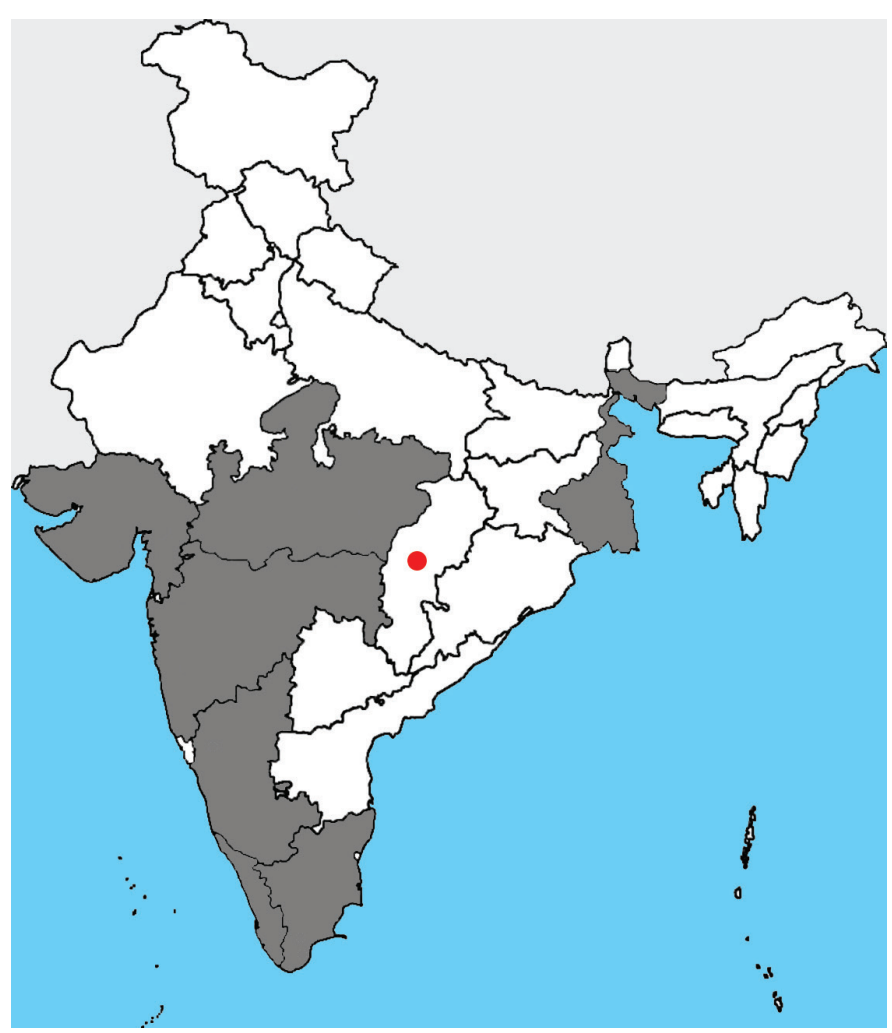

Fig. 2. Map of India showing states with records of Slender Coralsnakes (Calliophis melanurus) in dark gray. The site of the new Chhattisgarh state record in Durg is marked with the red dot.

and Bhosale 2012; Deshmukh et al. 2015; Melvinselvan et al. 2016; Nande and Deshmukh 2007; Narayanan et al. 2017; Sharma et al. 2015; Srinivasulu et al. 2014; Trivedi and Shah 2017; Vyas and Upadhaya 2008; Wall 1907; Walmiki et al. 2011). Srinivasulu et al. (2014; in a personal communication from Sanjay Thakur on p. 28) listed a locality for the species from Ambikapur, Surguja, Chhattisgarh. However, in another part of the document (pp. 54-55), the same species was treated as endemic to the Western Ghats and the central Indian locality was described as unconfirmed. Sharma et al. (2015) expressed doubt regarding the validity of that

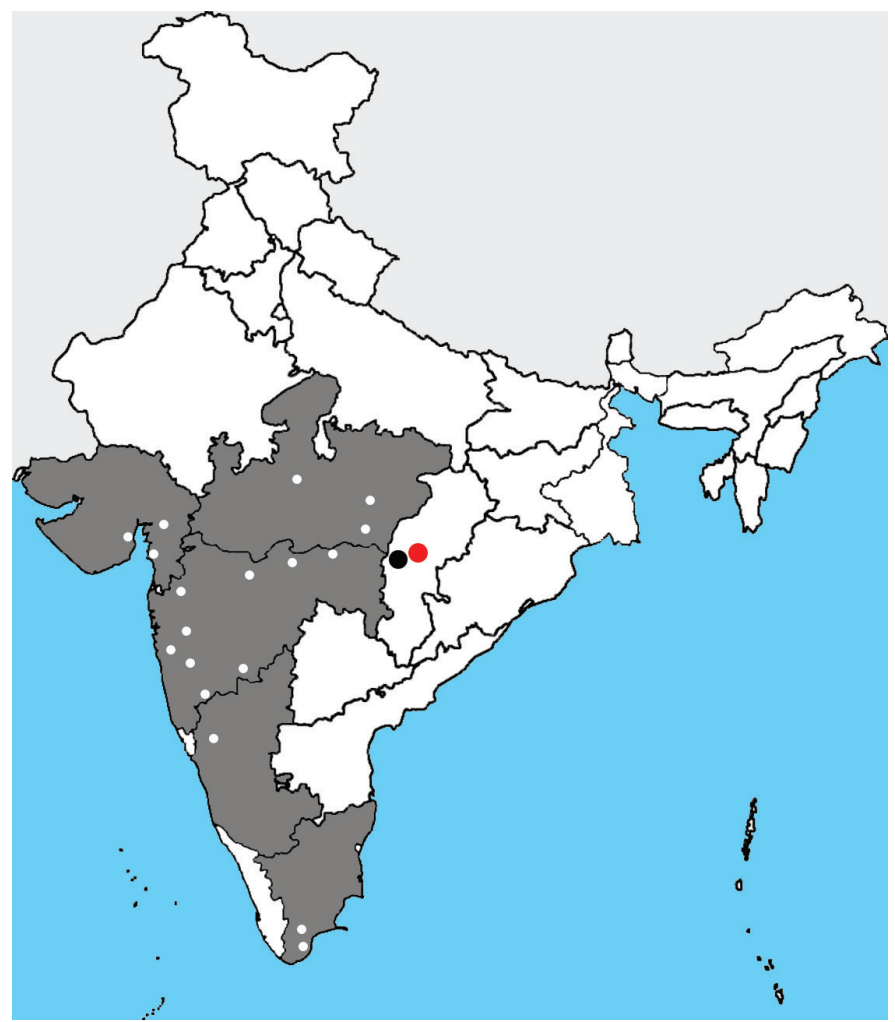

Fig. 4. Map of India showing states with records of Yellow-spotted Wolfsnake (Lycodon flavomaculatus) in dark gray and approximate localities of previous records as small white dots. The site of the new Chhattisgarh state record in Khairagarh is marked with the black dot and the new easternmost record of the species in Durg is marked with the red dot.

record. We herein present the first documented records from Chhattisgarh.

At $2150 \mathrm{~h}$ on 20 October 2017, the second author (SAD) encountered a young male (SVL $299.75 \mathrm{~mm}$, tail length $49.30 \mathrm{~mm}$; Fig. 3) while crossing the road into the campus of Indira Kala Sangit University in Khairagarh, Rajnandgaon District $\left(21^{\circ} 42 \times 15.93 » \mathrm{~N}, 80^{\circ} 97>85.06 » \mathrm{E}\right)$. After collecting morphological and meristic data and photographing the snake, he released it at the site of capture. At $2320 \mathrm{~h}$ on 22
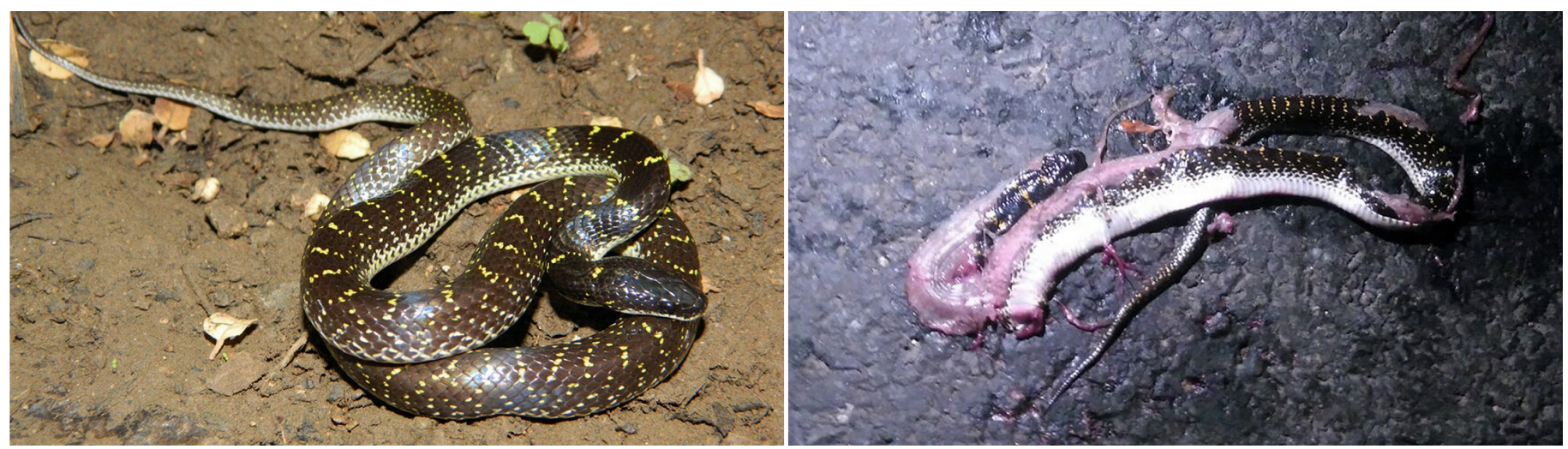

Fig. 3. A young Yellow-spotted Wolfsnake (Lycodon flavomaculatus) collected on 20 October 2017 in Khairagarh, Chhattisgarh, India (left) and a road-killed, unsexed individual found on 22 October 2017 in Durg, Chhattisgarh, India. These represent the first confirmed records of the species in Chhattisgarh. Durg is the easternmost recorded locality for the species in India. Photographs by Sagar Deshmukh. 
October 2017, SAD observed another young unsexed individual (Fig. 2) road-killed on the Balod Road near Bandha Talab in Durg $\left(21^{\circ} 18^{\prime} 12.18^{\prime \prime N}, 8^{\circ} 26^{\prime} 35.91^{\prime \prime} \mathrm{E}\right)$. The distance between these two localities (Fig. 4) was about $50 \mathrm{~km}$. Rajnandgaon is about 1,200 km from Dharwad, Karnataka (the type locality) for the Yellow-spotted Wolfsnake, $190 \mathrm{~km}$ east of the nearest known locality at Nagpur, Maharashtra, $738 \mathrm{~km}$ from a known locality in Vidisha, Madhya Pradesh, and $1,800 \mathrm{~km}$ from another locality in Nagalapuram, Tamil Nadu. Durg is the easternmost record for this species.

\section{Acknowledgements}

We thank Dr. Pratyush Mohopatra, Museum-in-Charge, ZSI, Central Zone Regional Centre, Jabalpur; Rahul Khot, Curator, Bombay Natural History Society, Mumbai, Maharashtra; Vithoba Hegde, BNHS; Dr. B.V. Jadhav, Head, Zoology Department, B.D. College, Patan, Satara; Dr. Rahul Khot, Curator, BNHS; Vithoba Hegade, BNHS; Swapnil Bhondawe; Sarang Hadke; Sushil Pillewan; Ajit Deshmukh; Ankush Kukde; Prajwal Raut; Gaurav Bhujade; Atul Bhelkar; Ashik Naitame; Raj Baghele; Ajay Pachare; Pankaj Bhivgade; Sandeep Shende; Lalit Nehare; Tushar Thakur; Shubham Katgube; and Manish Buche, Nagpur, for encouragement, support, and assistance in the field.

\section{Literature Cited}

Boulenger, G.A. 1893. Catalogue of the Snakes in the British Museum (Natural History. Volume I., Containing the Families Typhlopida, Glaudoniida, Boida, Ilysiida, Uropeltida, Xenopeltida, and Colubrida aglypha, part. Trustees of the British Museum, London, UK.

Chikane, S. and H.S. Bhosale. 2012. Reptiles of Kaas, Northern Western Ghats, Maharashtra, India, with notes on habitat preferences, abundances and threats. Sauria 34(3): 3-15.

D'Abreu, A.E. 1928. Records of the Nagpur Museum, No. VI. A List of Reptiles of the Central Province. Government Press, Nagpur, India.

Deepak, V., S. Harikrishnan, K. Vasudevan, and E.N. Smith. 2010. Redescription of Bibron's Coral Snake, Calliophis bibroni Jan 1858 with notes and new records from south of the Palghat and Shencottah Gaps of the Western Ghats, India. Hamadryad 35: 1-10.

Deshmukh, R.V., S.A, Deshmukh, and S.A. Badekar. 2015. Rescued records of snakes from Nagpur District, Maharashtra with data on unrecorded species. Reptile Rap 17: 34-43.
Ganesh, S.R. and E. Ramanujam. 2014. Rediscovery of Beddome's Coral Snake Calliophisbeddomei Smith, 1943 from the type locality. Journal of Threatened Taxa 6: 5580-5582.

Lenz, N. 2012. Von Schmetterlingen und Donnerdrachen - Natur und Kultur in Bhutan. Karlsruher Naturhefte 4. Naturkundemuseum Karlsruhe, Germany.

Lewis, T.R., S. Piggott, R. Griffin, P. Greig-Smith, G. Martins, G. Barretto, K. Bajibab, C. Thorpe-Dixon, P. Prodromou, M. Fordham, D. Willis, J. Turner, A. Radovanovic, D. Holloway, R. Wood, N. Hand, S. Lloyd, M. Clapson, J. Hennesy, and G. Oldham. 2010. Herpetological observations from field expeditions to North Karnataka and Southwest Maharashtra, India. Herpetological Bulletin (112): 17-37.

Melvinselvan [sic], G., R.S. Narayanan, and V. Sharma. 2016. Geographic distribution: Lycodon flavomaculatus (Yellow-spotted Wolf Snake). Herpetological Review 47: 427.

Nande, R. and S. Deshmukh. 2007. Snakes of Amravati District including Melghat, Maharashtra, with important records of the Indian Egg-eater, Montane Trinket Snake and Indian Smooth Snake. Zoos' Print Journal 22: 2920-2924.

Narayanan S., N. Joseph, M. Selvan, and A. Jerith. 2017. Notes on the southernmost distributional record for the Yellow-Spotted Wolfsnake, Lycodon cf. flavomaculatus (Wall 1907), from Tamil Nadu, India. Reptiles \& Amphibians 24: 115-117.

Palot, M.J. 2015. A checklist of reptiles of Kerala, India. Journal of Threatened Taxa 7: 8010-8022.

Sharma, V., A. Jain, and R. Bhandari. 2015. A new locality for the elusive and endemic Yellow-Spotted Wolf Snake (Lycodon flavomaculatus Wall 1907), with notes on distribution and habitat. Reptiles \& Amphibians 24: 164-167.

Shine, G. and P.O. Nameer. 2012. First record of Slender Coral Snake Calliophis melanurus (Shaw, 1802) south of the Palghat Gap, Western Ghats. Reptile Rap 14: 1-3.

Srinivasulu, C., B. Srinivasulu, and S. Molur. 2014. The Status and Distribution of Reptiles in the Western Ghats, India. Conservation Assessment and Management Plan (CAMP). Wildlife Information Liaison Development Society, Coimbatore, Tamil Nadu, India.

Trivedi, K. and V. Shah. 2017. Occurrence of the Yellow-Spotted Wolf Snake (Lycodon flavomaculatus Wall 1907) in Surat, Gujarat, India. Reptiles \& Amphibians 24: 201-202.

Uetz, P., P. Freed, and J. Hošek (eds.). 2018. The Reptile Database (http://www. reptile-database.org).

Vyas, R.V. and K. Upadhaya. 2008. On the occurrence of Lycodon flavomaculatus Wall, 1907 in Gujarat State, India. Sauria 30(1): 55-58.

Vyas, T.P. and M. Vyas. 1981. A note on the Slender Coral Snake, Callophis melanurus. Journal of the Bombay Natural History Society 78: 611-612.

Wall, F. 1907. Some new Asian snakes. Journal of the Bombay Natural History Society 17: 612-618.

Walmiki, N., D. Karangutkar, A. Jadhav, S. Parab, and N.S. Achyuthan. 2011. First record of Yellow-spotted Wolf Snake Lycodonflavomaculatus (Wall, 1907) from Chirner Forest, Uran, Maharashtra. Reptile Rap 12: 2-3.

Whitaker, R. and A. Captain. 2004. Snakes of India. The Field Guide. Draco Books, Chennai, India. 